\title{
Teachers' Professional Competence Development Working with Gifted Children
}

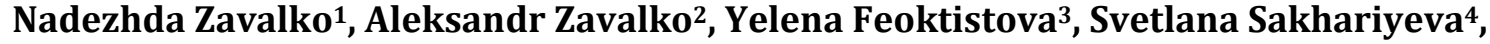 \\ Arfeniya Hachatryan ${ }^{3}$ \\ ${ }^{1}$ S. Amanzholov East-Kazakhstan State University, Ust-Kamenogorsk City, The Republic of Kazakhstan \\ ${ }^{2}$ D. Serikbayev East-Kazakhstan State Technical University, Ust-Kamenogorsk City, The Republic of Kazakhstan \\ ${ }^{3}$ Caspian State University of Technologies and Engineering Named after S. Yesenov, Aktau City, The Republic of \\ Kazakhstan \\ ${ }^{4}$ Moscow State University of Economics, Statistics and Computer Science, Moscow, Russia \\ Email: yelena976@gmail.com
}

Received 3 October 2014; revised 2 November 2014; accepted 8 November 2014

Copyright (C) 2014 by authors and Scientific Research Publishing Inc.

This work is licensed under the Creative Commons Attribution International License (CC BY). http://creativecommons.org/licenses/by/4.0/

c) (7) Open Access

\section{Abstract}

The paper specifies the notion "teachers' professional competence working with gifted children". Peculiarities of working with such children in the conditions of innovative schools in Kazakhstan are described. Content sand forms of work on the development of required competence are presented. Research experimental work results at Regional center "Daryn" on this direction were analyzed.

\section{Keywords}

Teacher's Professional Competence, Gifted Children, Innovative Schools, Gifted Children Competence Development

\section{Introduction}

Taking into account the fact that one of modern education actual objectives is creating conditions for revealing and developing gifted youth as potential intellectual and creative elite, providing competitiveness of any country, its progressive development and prosperity, it is important to develop teachers' professional competence working with gifted children. Transition to competence paradigm of professional education supposes training and formation of such a specialist who will easily adapt to constantly changing conditions, learn during all his life, possess new level of activity conceptualization, high expectations to himself and his work quality. A teacher, working with gifted children should possess a high level of intellect. He should be capable of solving tasks on the renewal of education contents and education technologies. Childish giftedness is being actualized in modern 
conditions.

In spite of a significant number of works, reflecting the variety of scientific ideas and practical approaches to the problem of personality giftedness, teachers working with gifted children professional competence research is not properly reflected in them. The issue of such teachers' advanced training remains open. The notion of "teacher's professional competence, working with gifted children" is determined on the assumption of basic "competence", which is the object of interdisciplinary research. References analysis allows us to state the fact that there is no unity in the issues of determining the essence of the notion "competence", its structure and content filling. Isayeva, T.Y. points out that competence can be referred to the category of macro concepts [1]. As complicated and organized system in the structure of a personality, it is connected with other structural components with different links, "penetrating" the personality at different levels. Thus, scholars are trying to find out the nature of contents and determine it through such notions, as knowledge, skills, abilities, qualities and features of the personality and its special abilities. Besides, competence like other components of personality structure cannot be completely empirically fixed.

Markova, A.K. determines the competence as: combination of psychic qualities, allowing acting independently and responsibly; the basis of judgments of a human is evaluation and measure of activity final result; competence is a characteristic of a separate person and is revealed in the results of his activity [2].

The goal of teacher's professional competence working with gifted children development dictates the necessity to find out the conditions of its achievement. The most important one of them is to determine components of the phenomenon under research. The paper makes an attempt to represent the structure of teacher's professional competence in the unity of components, criteria and indexes.

\section{Peculiarities of Work with Gifted Children}

On the basis of psychological and pedagogical references analysis the research has outlined the peculiarities, characterizing the process of working with gifted children, which are in the following: the use of special forms of student and teacher interaction, alternative styles of pedagogical communication; knowledge of psychological and psychic peculiarities of a gifted child; the use of special teaching strategies, and individual mentoring. These peculiarities are not complete, as they can vary and be supplemented taking into account the specificity of the educational establishment.

Practical activity experience shows that teacher's personality and the character of the relationship between the student and the teacher is one of the basic factors that stimulates giftedness revealing and developing. In this connection the use of mediation concept (Elkonin, B.D.) as a mechanism of interaction is the most productive. The essence of such concept is that the mediator as a co-participant in a child's development, taking into account his needs and possibilities leads him to the way of improvement [3].

It is necessary to point out that educational programs for gifted children are based on the combination of two main strategies "speeding" and "beneficiation". Special teaching strategies as "speeding" and "beneficiation" are widely used in the work with gifted children. Speeding is connected with tempo change, but not the content of education. Matyushkin, A.M. and Savenkov, A.I. stress the idea that "speeding" should be included in any program of teaching children with high intellectual development. Research conducted by a number of scholars [4] [5] has shown that "speeding" contributes to intellect development and does not harm communicative competences development. General requirements designed with the use of speeding should be the following: students demonstrate obvious interest and increased abilities in the area where speeding will be used; they should be mature enough socially and emotionally; and parents' consent is necessary. As a rule speeding is the best strategy for children with math abilities and inclination to foreign languages. There are several organizational forms of speeding: early start of school; speeding in a normal class; classes in another class: "skipping” one class; profile classes; radical speeding (possibility to study university program); and early entrance to university.

"Beneficiation" is a strategy, based on faster advancement to higher cognitive levels in the area of the chosen course, widening the area of knowledge at the expense of acquiring supplementary material to traditional contents courses. The strategy of "problematization" is another kind of qualitative change of education contents, supposing orientation for placing education problems for children.

\section{Contents and Forms of Developing Professional Competence Working with Gifted Children}

There is definite experience on in working with gifted children in Kazakhstan. There are specialized gymnasi- 
ums, lyceums, classes with advanced study of the courses, authorial and private schools. Competitions, Olympiads, tournaments, festivals, etc. are held. The university's best students have a chance to study abroad via "Bolashak" program. There is a system in the country to reveal, support and educate gifted children. According to the Decree of the President of the Republic of Kazakhstan No. 3002 of May, 24 ${ }^{\text {th }}, 1996$ "About state support and developing schools for gifted children" a research program was designed "Scientific-methodological fundamentals of gifted children and youth" [6]. State Program of the Republic of Kazakhstan on the support of young talents was developed to realize the system of work with gifted children, the goal of which is to determine basic strategy of search, up-bringing and education of gifted children and youth; support and development of unique ongoing process of the Republic of Kazakhstan intellectual potential formation; assistance in social-cultural development of talented youth [7].

On the basis of pedagogical systems theory, the system of teachers' professional competence development working with gifted children was designed (Figure 1) in the unity and interconnection of its components: goal,

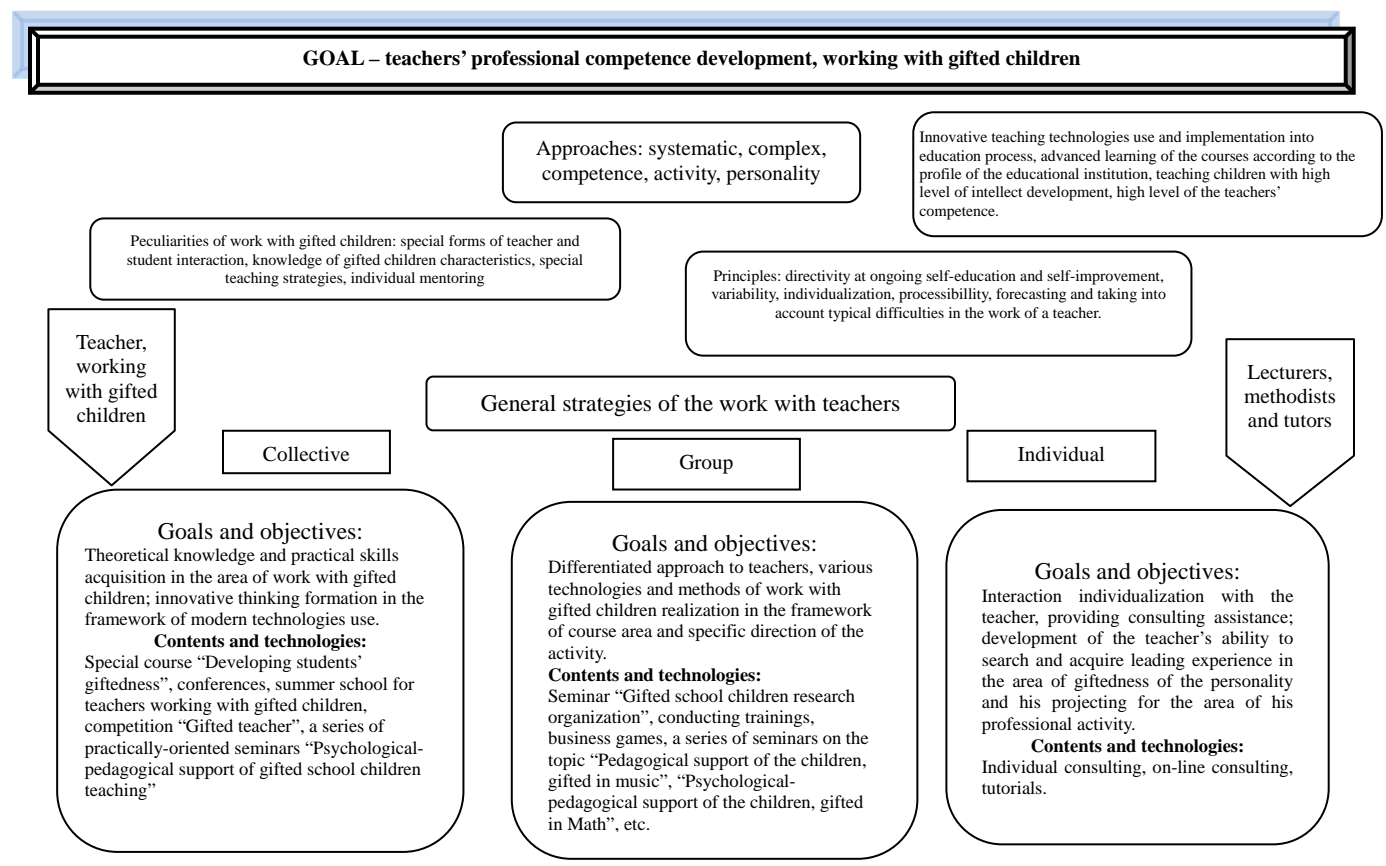

Teacher's activity on self-education

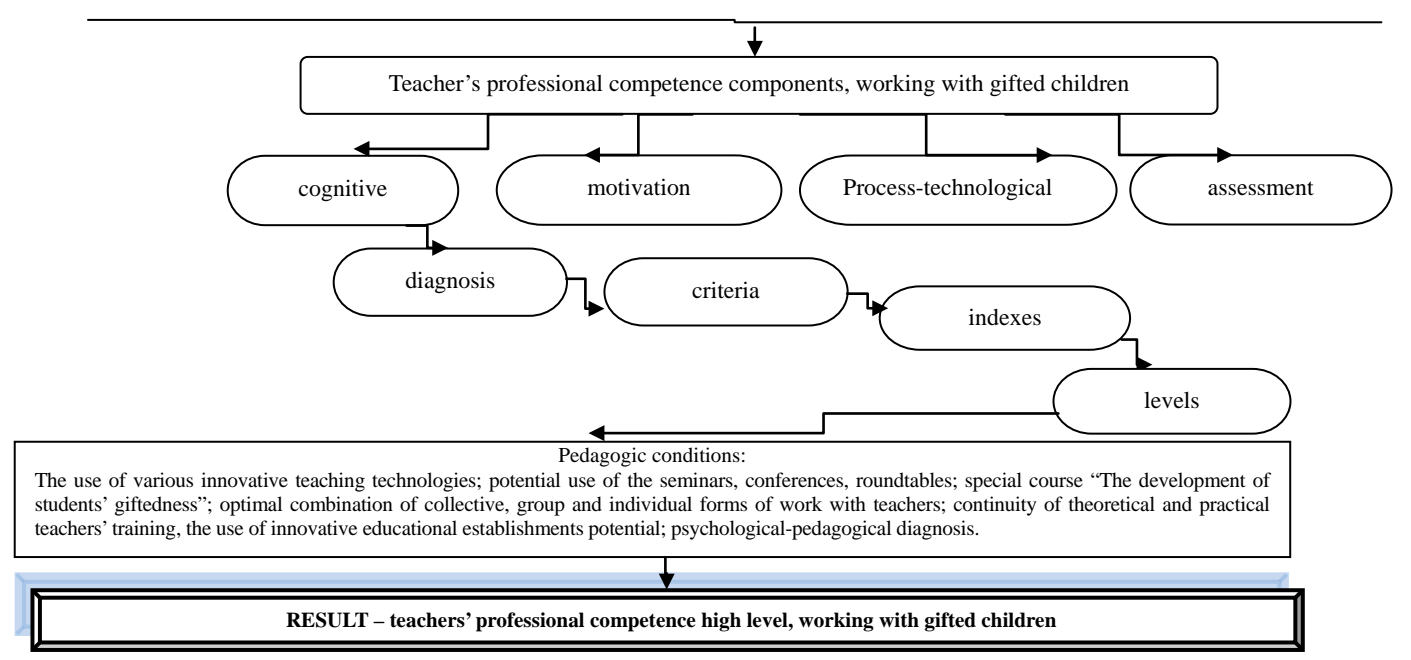

Figure 1. The scheme of teacher's professional competence development system, working with gifted children. 
principles, forms of organizing work with teachers, peculiarities, pedagogical conditions, subjects, participating in the process of education-up-bringing interaction, pedagogical conditions, levels and results. All the components of the system are in close relationship and interdependence. The change of compositional analysis entails the change of the system as a whole. The goal of the system is to develop teachers' professional competence, working with gifted children. The system is based on the following approaches: system, complex, competence, activity and personality.

General principles on which the system is based are: directivity to continuing self-education and self-improvement of the teacher, working with gifted children; variability; individualization; processibillity; forecasting and taking into account typical difficulties of the teacher, working with gifted children. The core of the system is contents and forms of teachers' advanced training work that can vary depending on the needs and demands of the listeners. Individual, pair and collective forms of work were used while research and also their combination with various active teaching methods, techniques and technologies.

Systematic and planned work on the teacher's qualification improvement working with gifted children will not be efficient without active activity of the teacher on self-education and self-improvement. The teacher's personality self-improvement is a conscious process of professional competence level increase and developing significant qualities according to social requirements of the society and personal program, directed at professional knowledge and skills improvement. It is necessary to underline that such activity is productive when it is voluntary and is directed by the person himself; necessity of some personal qualities improvement and when the person is aware of this fact. Activity on the teacher's self-education, working with gifted children will be efficient, when the teacher possesses developed ability to reflection and when during the process of self-education of the teacher information-communication methods are used and information-communication technologies environment is formed.

Pedagogic reflection is a necessary attribute of a teacher-professional. Reflection is a personality's activity, directed at conceptualization of the person's own actions, his inner feelings, conditions, experiences, analysis of this activity and formulating conclusions. While pedagogical activity analysis there is a necessity of theoretical knowledge acquisition, acquisition of pedagogical diagnosis, including self-diagnosis and students' diagnosis, acquiring practical skills of pedagogical experience analysis.

Pedagogical conditions, contributing to successful development of teachers' professional competence, working with gifted children are the following:

- the use of various innovative teaching technologies (information, telecommunication, communication, games), allowing to form the whole structure of future teachers' professional activity, working with gifted children with the aim of designing real context of professional activity;

- the use of seminars, conferences, round tables potential to acquire knowledge about the peculiarities of development, teaching and up-bringing gifted children, about the specificity of the teacher's professional activity, working with this category of children;

- inclusion in the contents of teachers' training a special course 'Students' personality giftedness development", supposing the realization of professional activity, directed at ways and experience acquisition and completion of specific professional actions;

- optimal combination of collective, group and individual forms of work with teachers, allowing to individualize this activity, approach existing problems differentially, solve contradictions, arising with teachers, working with gifted children;

- continuity of teachers' theoretic and practical training, supposing systematic and planned increase of education level and self-education;

- the use of innovative educational establishments potential to develop teachers' professional competence;

- purposeful and systematic psychological-pedagogical diagnosis.

\section{Conclusion}

Professional competence development in working with gifted children singled out conditions for further experimental research and development. Perspective directions of these problems are the following: design of didactical and scientific-methodical provision of the process; research of teachers' work succession with children at different school levels; university and advanced training centers for teachers cooperation in this work organization; and improvement of self-management in professional competence development, etc. 


\section{References}

[1] Isayeva, T.Y. (2006) Classification of Professional-Personality Competences of a University Lecturer. Pedagogy, 9, 55.

[2] Markova, A.K. (1990) Psychological Analysis of Teacher’s Professional Competence. Soviet Pedagogy, 8, 7.

[3] Elkonin, B.D. (2001) Development Psychology. Psychology, Moscow, 144.

[4] Savenkov, A.I. (2010) Children Giftedness Psychology. Genesis, Moscow, 440.

[5] Bogoyavlenskaya, D.B. (2002) Creative Abilities Psychology. 351.

[6] The Republic of Kazakhstan President Order No. 3002 of May, 1996 “About State Support and Development of Schools for Gifted Children” (1996) Astana, 1996.

[7] State Program of the Republic of Kazakhstan for the Support of Young Talents (2000) Astana, 2000. 
Scientific Research Publishing (SCIRP) is one of the largest Open Access journal publishers. It is currently publishing more than 200 open access, online, peer-reviewed journals covering a wide range of academic disciplines. SCIRP serves the worldwide academic communities and contributes to the progress and application of science with its publication.

Other selected journals from SCIRP are listed as below. Submit your manuscript to us via either submit@scirp.org or Online Submission Portal.
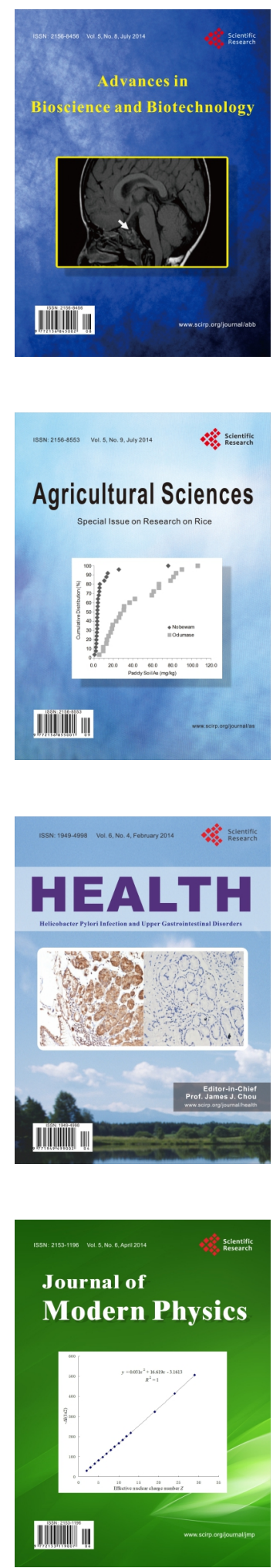
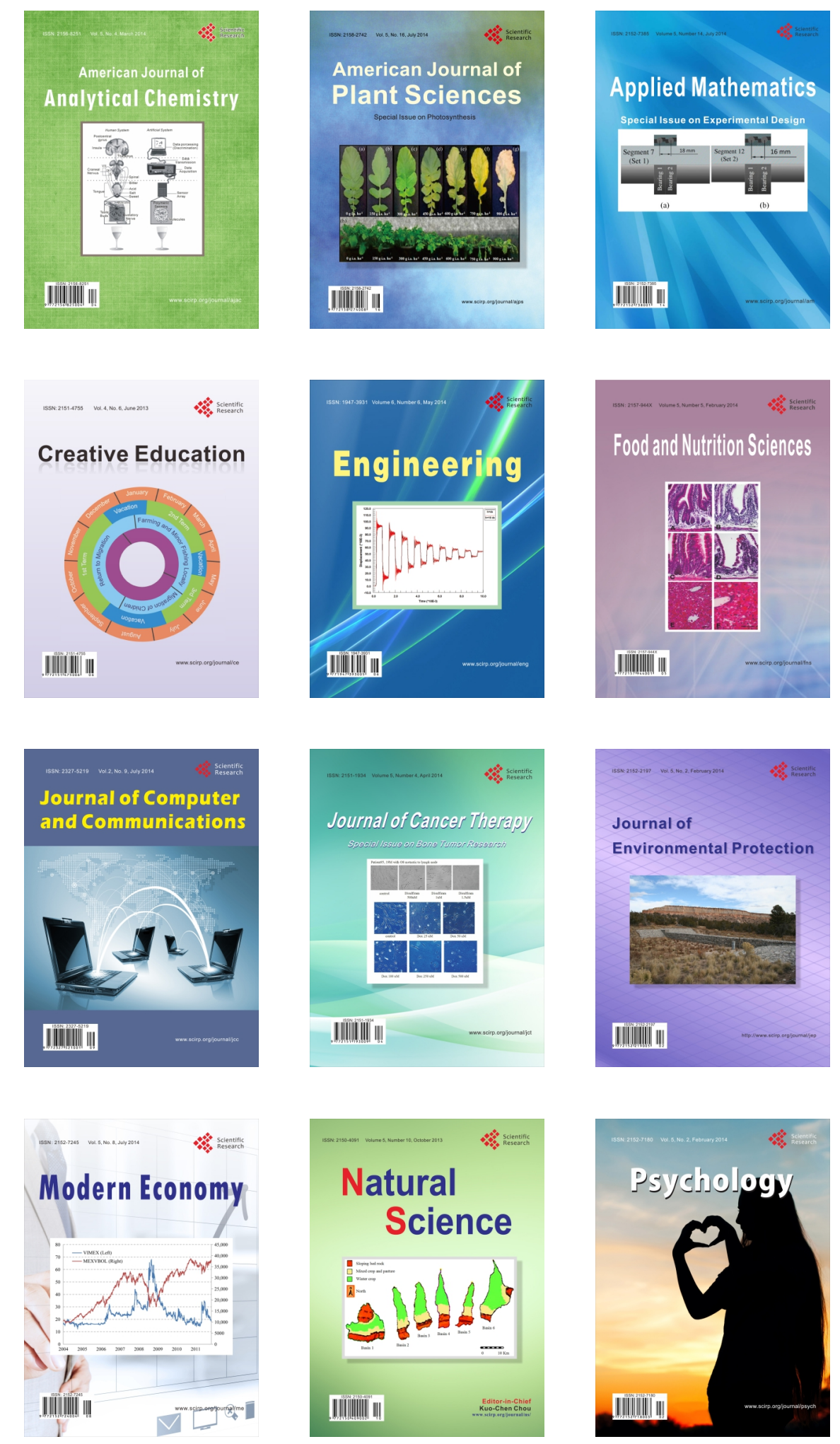